\title{
Macromedusae of Southern Brazil: temporal variation, population structure and biochemical composition
}

\author{
Fabiana Figueredo Molin De Barba, Carla Camila Bazi, Marcos Luiz Pessatti, Charrid Resgalla Jr* \\ Centro de Ciências Tecnológicas da Terra e do Mar (CTTMar) - Universidade do Vale do Itajaí (UNIVALI) \\ *Corresponding author: cresgalla@univali.br
}

\begin{abstract}
The objectives of this study were to record the macromedusae species on the north coast of Santa Catarina, and to estimate their population dynamics and variations in their biochemical composition, based on the specimens obtained in the by-catch of artisanal shrimp fishing between January 2012 and October 2014. Cohort analysis was performed to evaluate the population dynamic of the most frequent species. Biochemical analyses of the umbrellas were conducted on their water, carbohydrate, protein, lipid, ash and metals contents. Six species of macromedusae were found: Chiropsalmus quadrumanus and Tamoya haplonema (Cubozoa); Olindias sambaquiensis and Rhacostoma atlanticum (Hydrozoa), and Chrysaora lactea and Lychnorhiza lucerna (Scyphozoa). The species with the highest occurrence, and typical of the region, were Olindias sambaquiensis and Rhacostoma atlanticum. These species showed high inter-year variability, the highest densities being observed between autumn and winter 2014, associated with a less severe winter and coastal water with higher salinity. The distribution of size classes of $O$. sambaquiensis suggests two welldefined cohorts in spring/summer and in autumn/winter. $R$. atlanticum showed continuous reproduction and inter-year variation but a high value for protein content related to the reproductive peak in autumn. However, the Cubozoa species showed higher organic matter and metal content than the other classes.
\end{abstract}

Descriptors: Cnidaria, Megaplankton, Santa Catarina, Population dynamics, Bromatology, Metals.

\section{RESUMo}

O objetivo do presente estudo foi realizar um levantamento das espécies de macromedusas ocorrentes no Litoral Norte de Santa Catarina, avaliar sua dinâmica populacional e as variações na composição bioquímica, por meio de saídas de campo mensais, ocorridas entre janeiro de 2012 até outubro de 2014. As análises bioquímicas das umbrelas incluiram seu conteúdo em água, carboidratos, proteínas, lipídeos, cinzas, e, destas, sua composição. Foram encontradas seis espécies de macromedusas: Chiropsalmus quadrumanus e Tamoya haplonema (Cubozoa); Olindias sambaquiensis e Rhacostoma atlanticum (Hydrozoa); Chrysaora lactea e Lychnorhiza lucerna (Scyphozoa). As espécies de maior ocorrência e típicas da região foram Olindias sambaquiensis e Rhacostoma atlanticum. Ambas apresentaram alta variabilidade entre os anos, sendo que as maiores densidades foram obtidas entre o outono e o inverno de 2014, associadas a um inverno menos rigoroso e águas mais salgadas. As Cubozoas apresentam maior conteúdo em matéria orgânica, sendo as cinzas ricas em metais. $R$. atlanticum apresentou sazonalidade na composição química, estando as proteínas relacionadas com o pico reprodutivo da espécie.

Descritores: Cnidaria, Megaplâncton, Santa Catarina, Dinâmica populacional, Bromatologia, Metais. 


\section{INTRODUCTION}

According to PURCELL et al. (2007), medusae or jellyfish are marine organisms with widespread distribution in the oceans. In addition to their ecological importance, they are also of great interest in the areas of pharmacology and medicine, due to the bioactive compounds in their composition (WIEBRING et al., 2010). According to MORANDINI et al. (2005), they also have a marked impact on fishing, ecological and tourism activities, often causing accidents involving humans (HADDAD JÚNIOR et al., 2010). Cnidarians are animals with a rounded body and tentacles filled with stinging cells called nematocysts, which they use to capture prey and as defense organelles. They are aquatic invertebrates, predominantly marine, colonial or solitary, with a life cycle that alternates between a polyp (asexual) phase and a medusa (sexual) phase (RAMIREZ; ZAMPONI, 1981).

Among the classes of Cnidaria, there are approximately 200 species of Scyphozoa worldwide, 22 of them having been recorded in Brazil. For Cubozoa, only 20 species have been described, with four recorded in Brazil (MORANDINI et al., 2005) and for hydrozoa, a more diverse class, the number of species may be higher than 348 , according to the most recent revision, presented by MARQUES et al. (2003).

Reports of an increase in the biomass of free-living cnidaria are increasing all over the world (PURCELL et al., 2007). This increase may be related to factors such as pollution of the seas, overfishing of predators, warming up of the marine waters, and invasions (MILLS, 2001).

One of the few opportunities to obtain information on these organisms is fishing records. As a result, recent studies involving the capture of macrozooplankton have been carried out for both artisanal fishing (BRANCO; VERANI, 2006; NOGUEIRA JÚNIOR; HADDAD, 2006a; NAGATA et al., 2009) and industrial fishing (SCHROEDER et al., 2014). In many cases, these are the only records available on the abundance and distribution of the group, due to the sampling limitations applied to marine plankton.

Due to these information gaps about the group, the objectives of this study were to record the macromedusae species on the north coast of Santa Catarina, to estimate their population dynamics by class size distribution, and to biochemically characterize the umbrellas of the incident species obtained in the artisanal shrimp fishing by-catch between January 2012 and October 2014.

\section{MATERIAL AND METHODS}

\section{SAMPLING}

Macromedusae samples were obtained in the 33 months between February 2012 and October 2014, as a by-catch of the artisanal shrimp fishing off the north coast of Santa Carina, which operated between isobaths of 15 and 20 meters and on $25 \mathrm{Km}$ of the coast $\left(26^{\circ} 45^{\prime}\right.$ to $27^{\circ}$ $00^{\prime} \mathrm{S}$ ) (Figure 1) on two fishing trips per month. The trawls were performed from a motorized boat using nets with a mesh size of $50 \mathrm{~mm}$ between opposite knots in the body and $30 \mathrm{~mm}$ in the bagger, with a length of 14 meters and opening of 5 meters. Data on water temperature and salinity were also obtained using a YSI 30 thermosalinometer. The organisms obtained were packaged in coolers and transported to the laboratory, where they were washed in fresh water, weighed, and measured individually with an ictiometer. After the biometrics, the organisms were frozen for subsequent biochemical analysis.

\section{BIOCHEMICAL ANALYSES}

The water content was determined gravimetrically by freeze-drying in a lyophilizer. The protein content was determined by the Kjeldahl method (AOAC, 1995) with digestion in sulfuric acid, the distillate being titrated in hydrochloric acid standard solution. The method used to determine the lipid content was performed by extraction in petroleum ether, according to VON SOXHLET (1879). The dosage of carbohydrates, by total hexose, followed the method proposed by DUBOIS et al. (1956) with hydrolysis in strong acid $\left(6.0 \mathrm{M}\right.$ of Trifluoroacetic acid - TFA, at $100^{\circ} \mathrm{C}$ for $5 \mathrm{~h}$ ) and dosage per standard curve of galactose. Ash was determined by burning the dry material in a muffle furnace at $550^{\circ} \mathrm{C}$ for $2 \mathrm{~h}$.

The lyophilized samples of umbrellas of medusas, obtained at various times of the year, were mixed in equal amounts and homogenized by grinding. The exception was $R$. atlanticum, for which seasonal estimates of the protein, lipid and carbohydrate contents were determined. Due to the rarity of occurrence of $L$. lucerne, no lipid estimates were made for this species. All analyses were performed in duplicate (carbohydrates) or in quadruplicate (water, protein and lipid contents).

\section{ANALYSIS OF METALS IN ASH}

After burning the tissues in the muffle furnace, the metal content of $\mathrm{Al}^{3+}, \mathrm{Ba}^{+}, \mathrm{Ca}^{2+}, \mathrm{Pb}^{4+}, \mathrm{Co}^{2+}, \mathrm{Cu}^{2+}, \mathrm{Cr}^{3+}, \mathrm{Sr}^{2+}$, 


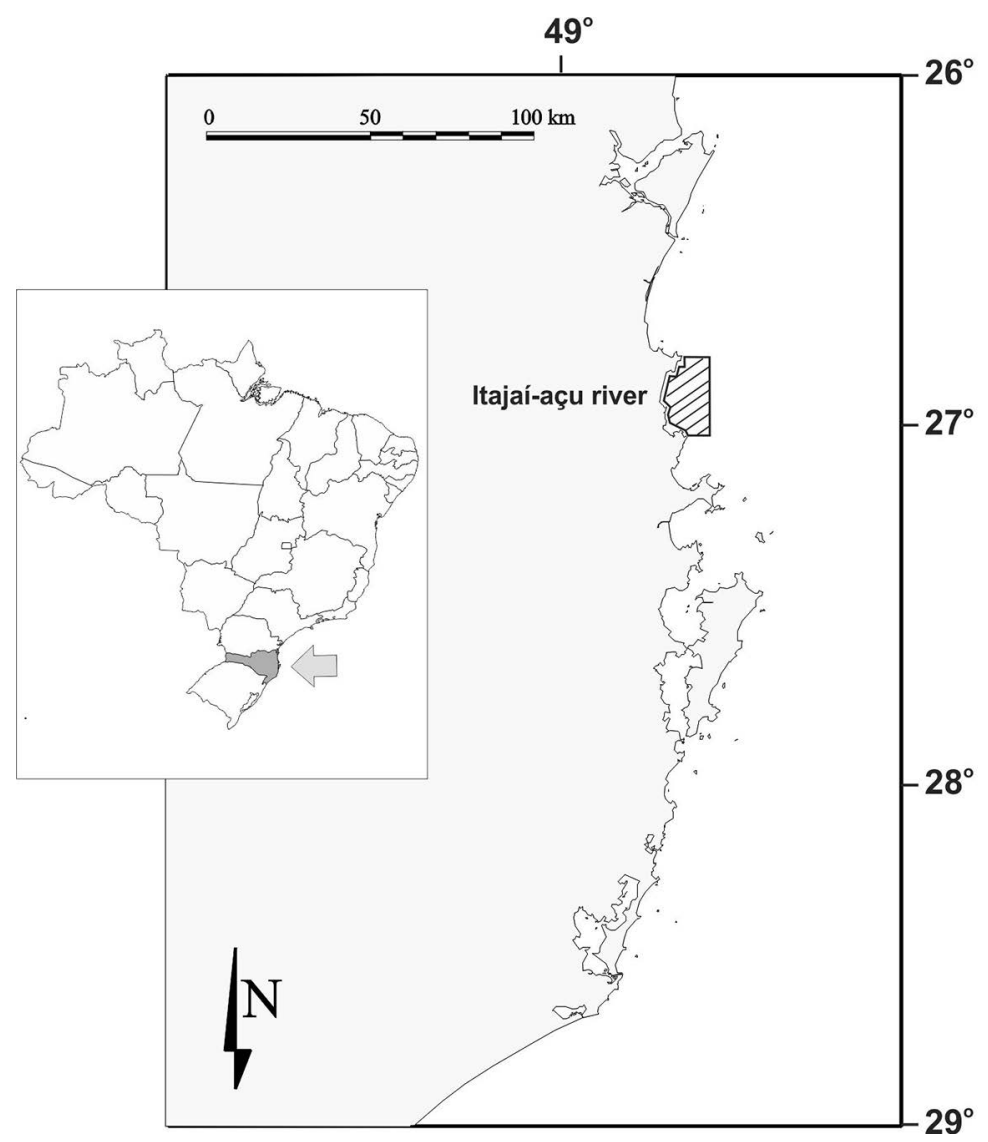

Figure 1. Coast of Santa Catarina and shrimp artisanal fishing area (marked area) used to obtain macromedusae specimens.

$\mathrm{Fe}^{2+}, \mathrm{Mg}^{2+}, \mathrm{Mn}^{2+}, \mathrm{Hg}^{2+}, \mathrm{Ni}^{2+}, \mathrm{K}^{+}$and $\mathrm{Zn}^{2+}$ were determined in the ash by digestion in heated nitric acid. The solution was read in an EAA Varian atomic absorption spectrophotometer, model AA/55, Varian model VGA 77 steam generation accessory, and Varian SIPS peristaltic sample introduction system (EATON et al., 1992).

\section{ANALYSIS OF THE DATA}

Catch data for jellyfish obtained in the fishing net hauls were standardized by number of organisms per 10 minutes of trawl time, based on time variability of the different trawls and data grouped in monthly catches. The data represent the Catch Per Unit of Effort (CPUE) or density estimate. The biometric data were grouped into size classes, and based on the distribution of frequency a cohort analysis was performed by displacement of the modes, in order to evaluate the population dynamic of the most frequent species. Diameter/length and weight ratios were determined for the species in order to estimate the biomass.

\section{RESULTS}

For the thirty-three-month sampling period, a temperature seasonality was observed on the surface, with a maximum in summer and a minimum in the winter for the year 2013 (Figure 2). In relation to depth (15 to $20 \mathrm{~m}$ ), low temperature values were recorded for the summer months in all the years. Low salinity values were observed in the winter months, both on the surface and at the bottom. However, for 2014, the winter was less severe in terms of temperature and salinity.

Six species of macromedusae were recorded on the northern coast of Santa Catarina. The most abundant were Olindias sambaquiensis and Rhacostoma atlanticum (Hydrozoa), followed by Chrysaora lactea (Scyphozoa) and Chiropsalmus quadrumanus (Cubozoa), the least abundant being Lychnorhiza lucerne (Scyphozoa) and Tamoya haplonema (Cubozoa) (Table 1).

The largest catches of organisms were recorded in summer/autumn 2014, but the occurrences were 

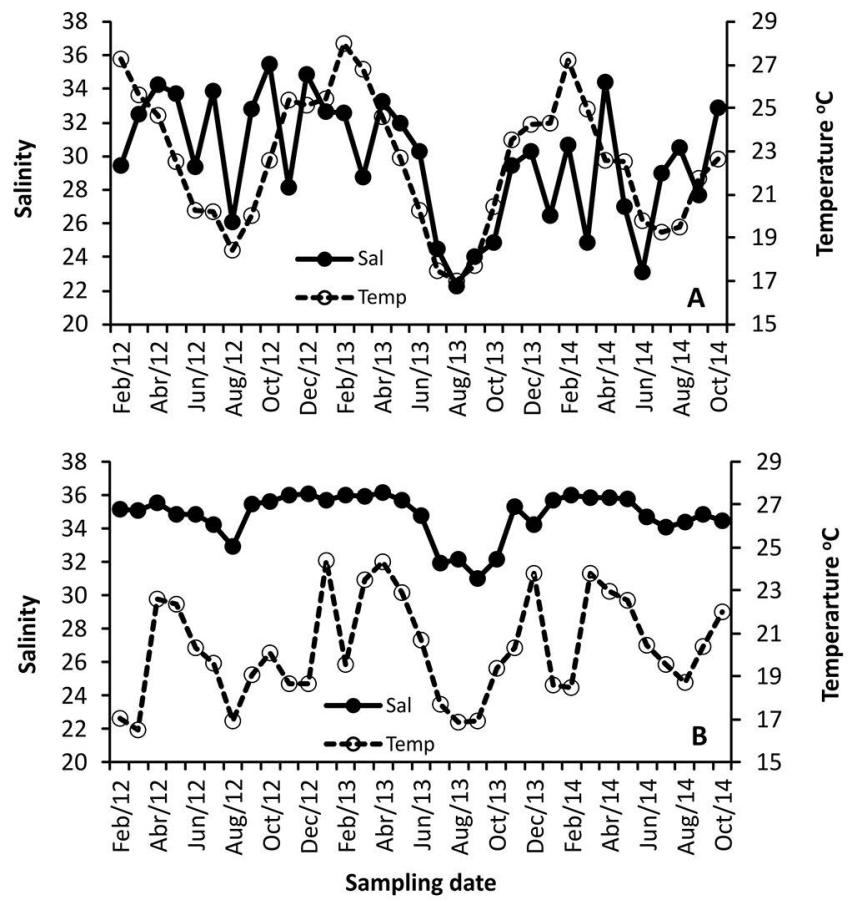

Figure 2. Variation of salinity and temperature on the surface (A) and bottom (B) during the sampling period.

Table 1. Frequency of occurrence and catch per unit of effort for the species of macromedusae recorded on the north coast of Santa Catarina.

\begin{tabular}{lcc}
\hline Species & $\begin{array}{c}\text { Frequency of } \\
\text { Occurrence }\end{array}$ & $\begin{array}{c}\text { Catch per 10 minutes } \\
\text { of trawling (average) }\end{array}$ \\
\hline $\begin{array}{l}\text { Olindias sambaquiensis } \\
\text { (Müller, 1861) }\end{array}$ & 75.76 & 4.99 \\
$\begin{array}{l}\text { Rhacostoma atlan- } \\
\text { ticum (L. Agassiz, }\end{array}$ & 63.64 & 4.21 \\
$\begin{array}{l}\text { 1850) } \\
\text { Chiropsalmus qua- } \\
\text { drumanus (F. Müller, }\end{array}$ & 45.45 & \\
$\begin{array}{l}\text { 1859) } \\
\text { Chrysaora lactea } \\
\text { (Eschscholtz, 1829) }\end{array}$ & 33.33 & 0.39 \\
$\begin{array}{l}\text { Lychnorhiza lucerna } \\
\text { (Haeckel, 1880) }\end{array}$ & 9.09 & 0.53 \\
$\begin{array}{l}\text { Tamoya haplonema (F. } \\
\text { Müller, 1859) }\end{array}$ & 21.21 & 0.13 \\
\hline
\end{tabular}

distributed throughout the year, with lower catches in the winter months (Figure 3). In general $O$. sambaquiensis and $R$. atlanticum determined the general behavior of the density of macromedusae on the coast, the former species with occurrences in the autumn and spring and the latter species in the hot summer months. The other species had reported occurrences in the summer and autumn.
The species with the highest occurrence $(O$. sambaquiensis and $R$. atlanticum) presented different reproduction strategies, as suggested by the frequency distribution of size classes (Figures 4 and 5). For $O$. sambaquiensis, which presents density peaks in autumn and spring, the distribution of its size classes suggests two well-defined cohorts throughout the year; one from spring to summer, and the other from autumn to winter (Figure 4).

$R$. atlanticum occurred throughout the year and in different size classes, but with density peaks in summer (Figure 5). The distribution of its size classes suggests continuous reproduction throughout the year, but with overlapping cohorts in the warmer months of summer and autumn.

For 2014, O. sambaquiensis presented cohorts in higher densities, while $R$. atlanticum presented, in addition to high densities, a greater number of cohorts in relation to the other years.

Figures 6 and 7 present the relationships between the size and weight of the species occurring on the north coast of Santa Catarina. These correlations are useful for estimating the biomass of the group.

In general, macromedusae present high water content $(>95 \%)$, with cubozoas being richer in organic matter, with higher protein, lipid and 


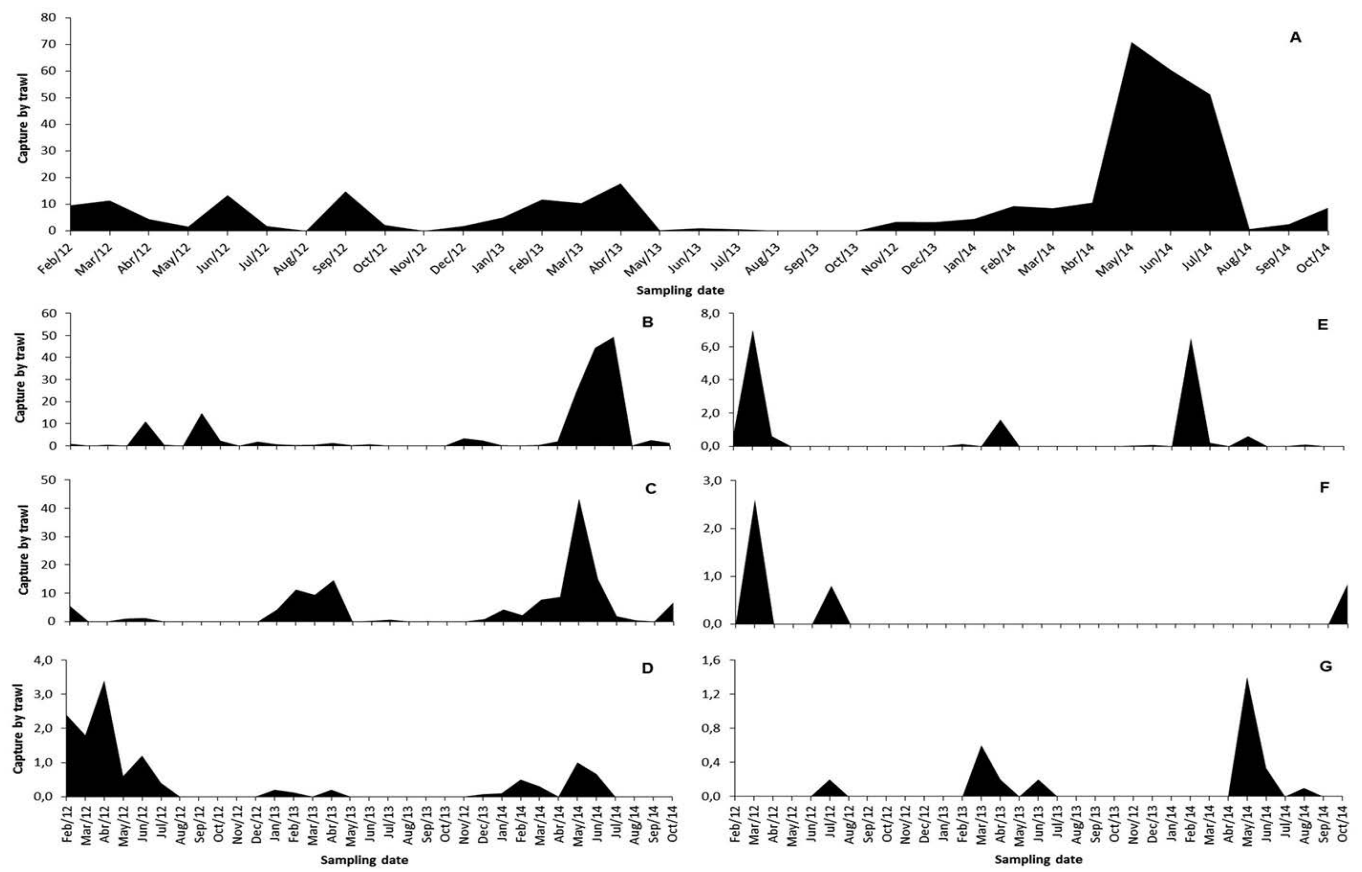

Figure 3. Temporal variation in the number of organisms caught per 10 minutes of trawl on the north coast of Santa Catarina between 2012 to 2014. $\mathrm{A}=$ Total macromedusae, $\mathrm{B}=O$. sambaquiensis, $\mathrm{C}=R$. atlaticum, $\mathrm{D}=C$. quadrumanus, $\mathrm{E}=C$. lactea, $\mathrm{F}=$ L. lucerna and $\mathrm{G}=T$. haplonema .

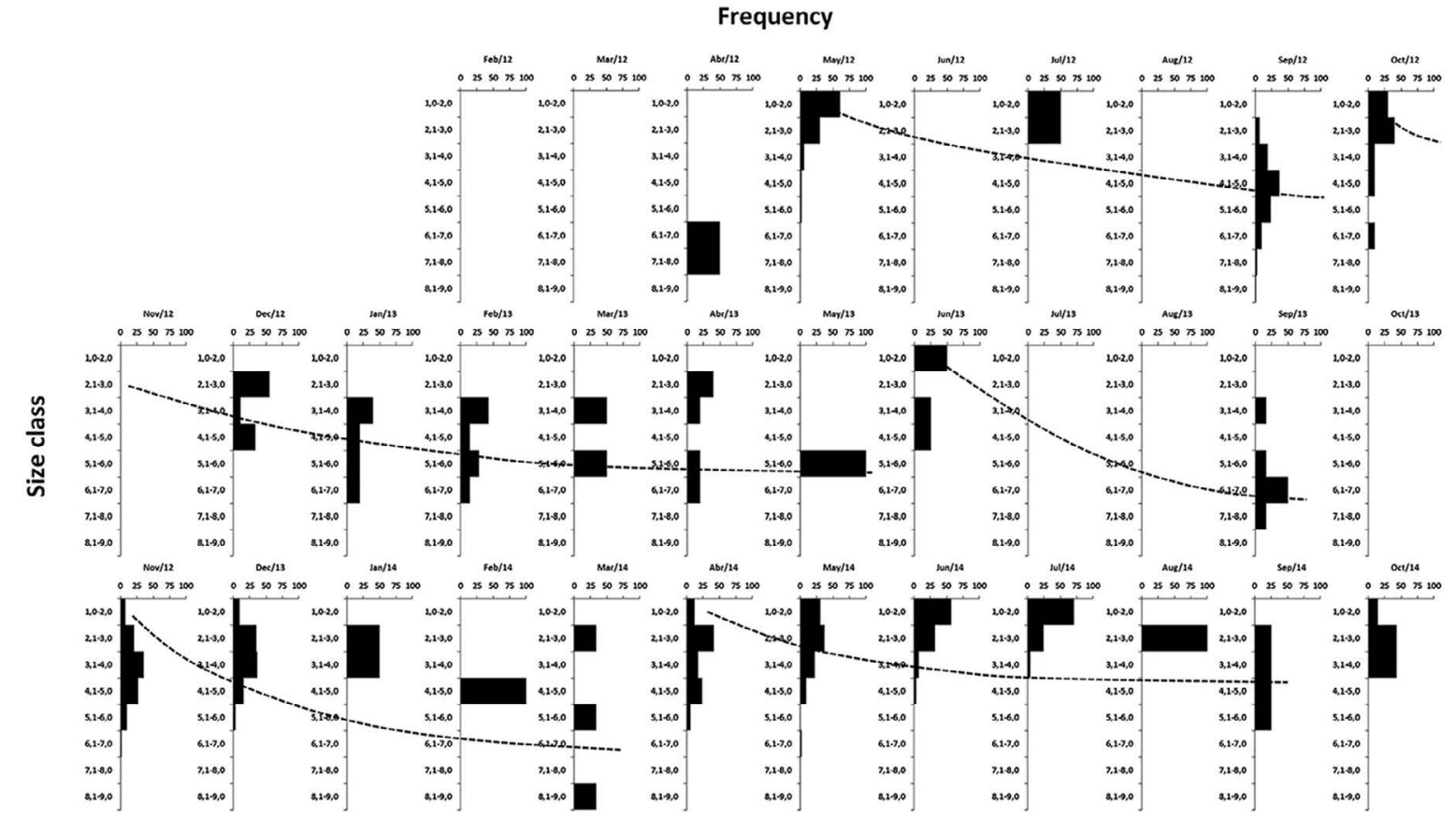

Figure 4. Frequency distribution of size classes of $O$. sambaquiensis for the sampling period and with the probable existing cohorts.

carbohydrate values (Table 2) and the lowest values in ash. The analysis of metals in ash highlighted that macromedusae are rich in $\mathrm{Mg}^{2+}, \mathrm{K}^{+}$and $\mathrm{Ca}^{+2}$ as major and in $\mathrm{Sr}^{2+}$ and $\mathrm{Cu}^{2+}$ as minor constituents (Table 3). It is emphasized that C. quadrumans has an enriched metal constitution in $\mathrm{Al}^{3+}, \mathrm{Fe}^{2+}$ and $\mathrm{Mn}^{2+}$ in relation to the other species.

For $R$. atlanticum, a species with high occurrence reported by industrial fisheries in the south of Brazil (SCHROEDER et al., 2014), seasonal variations of 


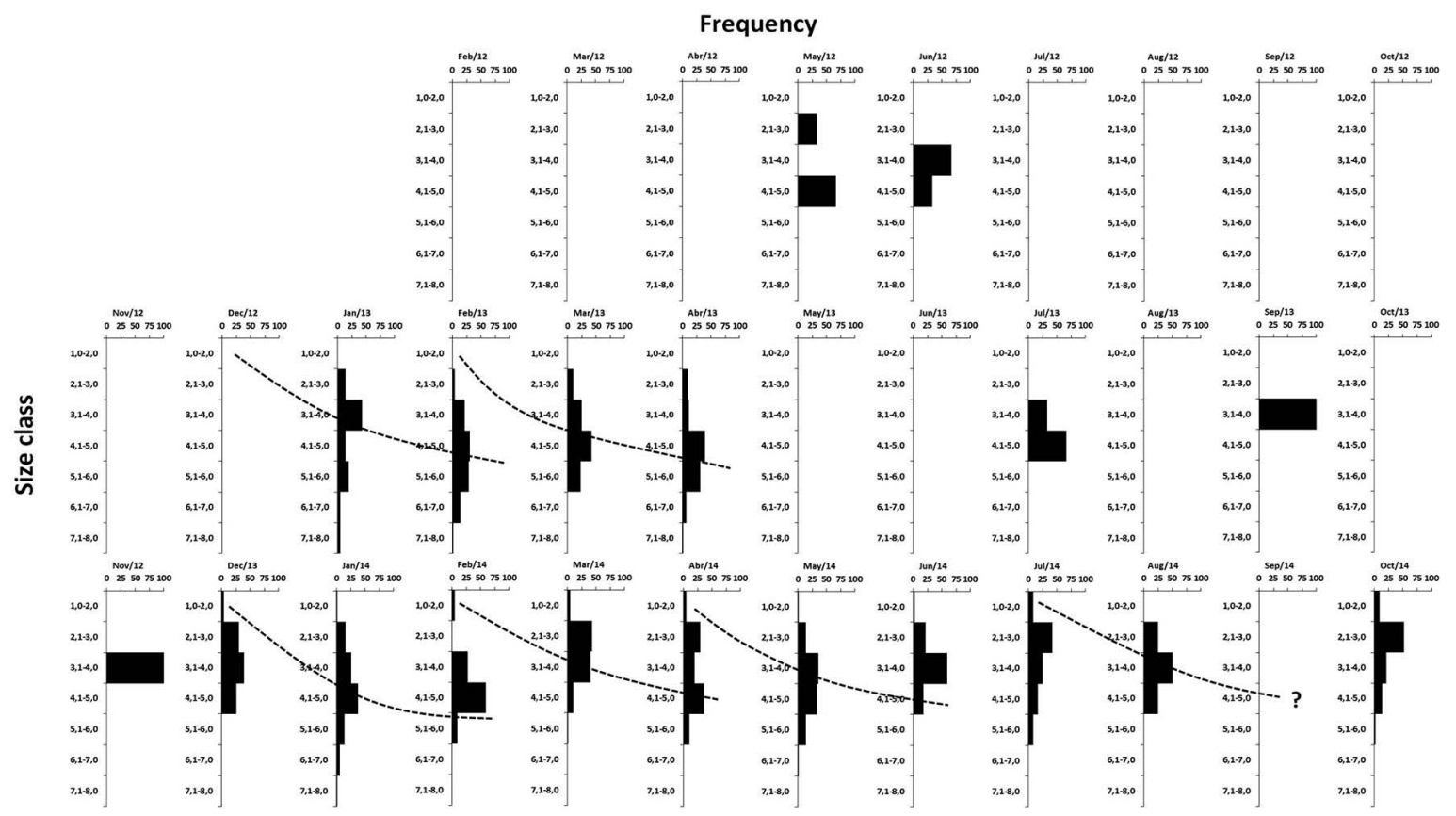

Figure 5. Frequency distribution of size classes of $R$. atlanticum for the sampling period and with the probable existing cohorts.
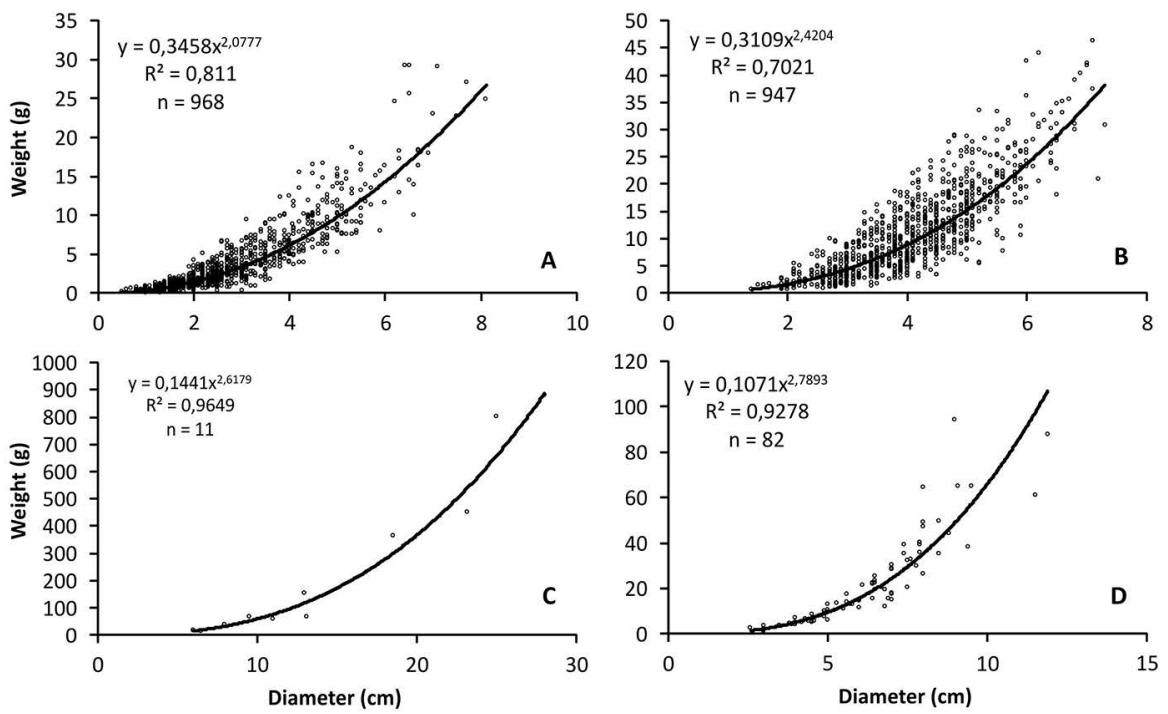

Figure 6. Relationship between diameter $(\mathrm{cm})$ and weight $(\mathrm{g})$ for Hidrozoa and Scyphozoa occurring on the north coast of Santa Catarina, A $=O$. sambaquiensis, $\mathrm{B}=R$. atlanticum, $\mathrm{C}=L$. lucerna and $\mathrm{D}=C$. lactea .

its chemical composition showed the highest protein content and low lipids in the autumn, and high carbohydrate content in the spring (Figure 8).

\section{DISCUSSION}

The north coast of Santa Catarina presents marked seasonality in terms of temperature, influenced by warm waters of the Brazil Current and the cold waters of the La Plata Front (PIOLA et al., 2005) and salinity controlled by the continental drainage that alters the composition of the zooplankton community (RESGALLA JR., 2011). This complexity is further compounded by the processes of upwelling induced by the northeasterly winds, which lowers the bottom temperatures during the summer period (CARVALHO et al., 1998), as recorded in this study. These 

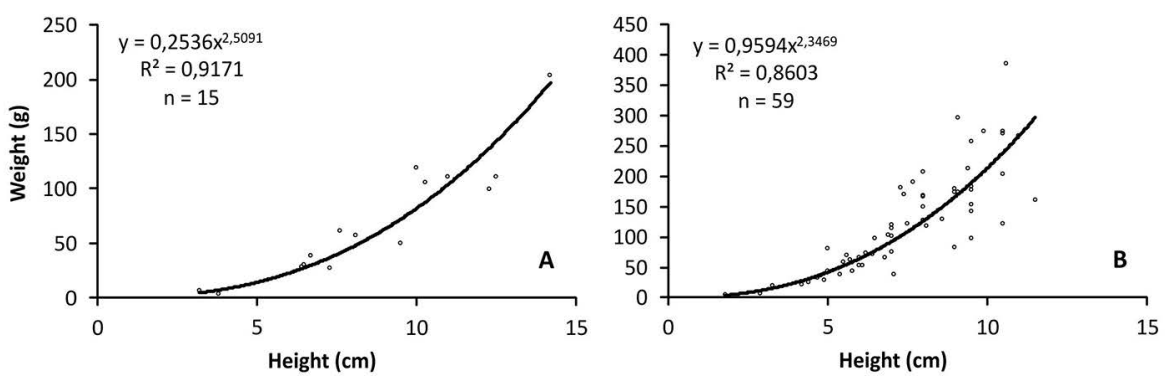

Figure 7. Relationship between height $(\mathrm{cm})$ and weight $(\mathrm{g})$ for Cubozoa occurring on the north coast of Santa Catarina, $\mathrm{A}=$ T. haplonema and $\mathrm{B}$ $=$ C. quadrumanus.

Table 2. Average percentages (\%) and standard deviation of water in fresh mass and ash, carbohydrates, proteins and lipids in dry mass of the species of macromedusae occurring on the north coast of Santa Catarina.

\begin{tabular}{lccccc}
\hline \multirow{2}{*}{ Species } & \multirow{2}{*}{ Water } & Carbohydrates & Proteins & Lipids & Ash \\
\hline C. quadrumanus & $95.78 \pm 0.82$ & $5.92 \pm 0.30$ & $18.24 \pm 0.02$ & $1.31 \pm 0.00$ & $57.20 \pm 0.01$ \\
O. sambaquiensis & $96.76 \pm 0.36$ & $4.68 \pm 0.21$ & $14.19 \pm 0.02$ & $1.63 \pm 0.36$ & $62.99 \pm 0.01$ \\
R. atlanticum & $96.86 \pm 0.61$ & $1.24 \pm 0.15$ & $10.55 \pm 0.01$ & $1.40 \pm 0.14$ & $70.68 \pm 0.01$ \\
T. haplonema & $96.03 \pm 0.00$ & $4.21 \pm 0.00$ & $27.66 \pm 0.03$ & $3.74 \pm 0.37$ & $51.15 \pm 0.00$ \\
C. lactea & $95.10 \pm 0.40$ & $0.94 \pm 0.11$ & $12.64 \pm 0.01$ & $1.84 \pm 1.07$ & $65.20 \pm 0.01$ \\
L. lucerna & $96.29 \pm 0.45$ & $2.73 \pm 0.04$ & $12.29 \pm 0.03$ & - & $58.24 \pm 0.08$ \\
\hline
\end{tabular}

Table 3. Composition of metals in the ash of species of macromedusae occurring on the north coast of Santa Catarina. R.a. $=R$. atlanticum, O.s. =O. sambaquiensis, L.1. = L. lucerna, T.h. =T. haplonema, C.q. =C. quadrumanus, C.1. =C. lactea .

\begin{tabular}{|c|c|c|c|c|c|c|c|}
\hline Metals & Unit & R.a. & O.s. & L.1. & T.h. & C.q. & C.1. \\
\hline $\mathrm{Al}^{3+}$ & $\mathrm{mg} \cdot \mathrm{kg}^{-1}$ & nd & nd & nd & nd & 189.0 & nd \\
\hline $\mathrm{Ba}^{2+}$ & $\mathrm{mg} \cdot \mathrm{kg}^{-1}$ & $<2.5$ & $<2.5$ & $<2.5$ & $<2.5$ & $<2.5$ & nd \\
\hline $\mathrm{Ca}^{2}+$ & g. $\mathrm{kg}^{-1}$ & 11.48 & 10.13 & 11.84 & 10.78 & 13.2 & 10.94 \\
\hline $\mathrm{Pb} 4+$ & $\mathrm{mg} \cdot \mathrm{kg}^{-1}$ & $<2.5$ & 4.7 & 4.9 & 3.7 & 4.6 & 2.9 \\
\hline $\mathrm{Co}^{2+}$ & $\mathrm{mg} \cdot \mathrm{kg}^{-1}$ & nd & nd & nd & nd & nd & nd \\
\hline $\mathrm{Cu}^{2+}$ & $\mathrm{mg} \cdot \mathrm{kg}^{-1}$ & 34.6 & 38.1 & 22.4 & 29.5 & 36.2 & 22.3 \\
\hline $\mathrm{Cr}^{3}+$ & $\mathrm{mg} \cdot \mathrm{kg}^{-1}$ & nd & $<2.5$ & nd & nd & 3.3 & nd \\
\hline $\mathrm{Sr}^{2+}$ & $\mathrm{mg} \cdot \mathrm{kg}^{-1}$ & 191 & 175 & 211 & 195 & 198 & 206 \\
\hline $\mathrm{Fe}^{2+}$ & $\mathrm{mg} \cdot \mathrm{kg}^{-1}$ & 3.3 & 2.9 & 7.0 & 3.9 & 182.0 & $<2.5$ \\
\hline $\mathrm{Mg}^{2+}$ & g. $\mathrm{kg}^{-1}$ & 40.21 & 35.00 & 42.61 & 37.92 & 39.57 & 38.95 \\
\hline $\mathrm{Mn}^{2+}$ & $\mathrm{mg} . \mathrm{kg}^{-1}$ & $<2.5$ & $<2.5$ & $<2.5$ & $<2.5$ & 12.1 & $<2.5$ \\
\hline $\mathrm{Hg}^{2}+$ & $\mathrm{mg} \cdot \mathrm{kg}^{-1}$ & nd & nd & nd & nd & nd & nd \\
\hline $\mathrm{Ni}^{2}+$ & $\mathrm{mg} \cdot \mathrm{kg}^{-1}$ & nd & nd & nd & nd & $<2.5$ & nd \\
\hline $\mathrm{K}+$ & g. $\mathrm{kg}^{-1}$ & 35.04 & 33.08 & 21.15 & 30.64 & 32.97 & 19.66 \\
\hline $\mathrm{Zn}^{2+}$ & mg.kg-1 & 2.9 & 10.3 & 8.4 & 25.6 & 17.5 & 14.8 \\
\hline
\end{tabular}

oceanographic variations can exercise great influence on the occurrence and distribution of macromedusae species, particularly in relation to their life cycle.

This hydrological complexity may explain the occurrence of macromedusae species with different tolerances to the different water bodies in the study area.
The species with further southward distribution to the south of Brazil, such as Rhacostoma atlanticum and Olindias sambaquiensis, are typical of the region, but there also occur warmer water species, with distribution between the coast of Paraíba and São Paulo, such as Chrysaora lactea, Chiropsalmus quadrumanus, Lychnorhiza lucerna and 

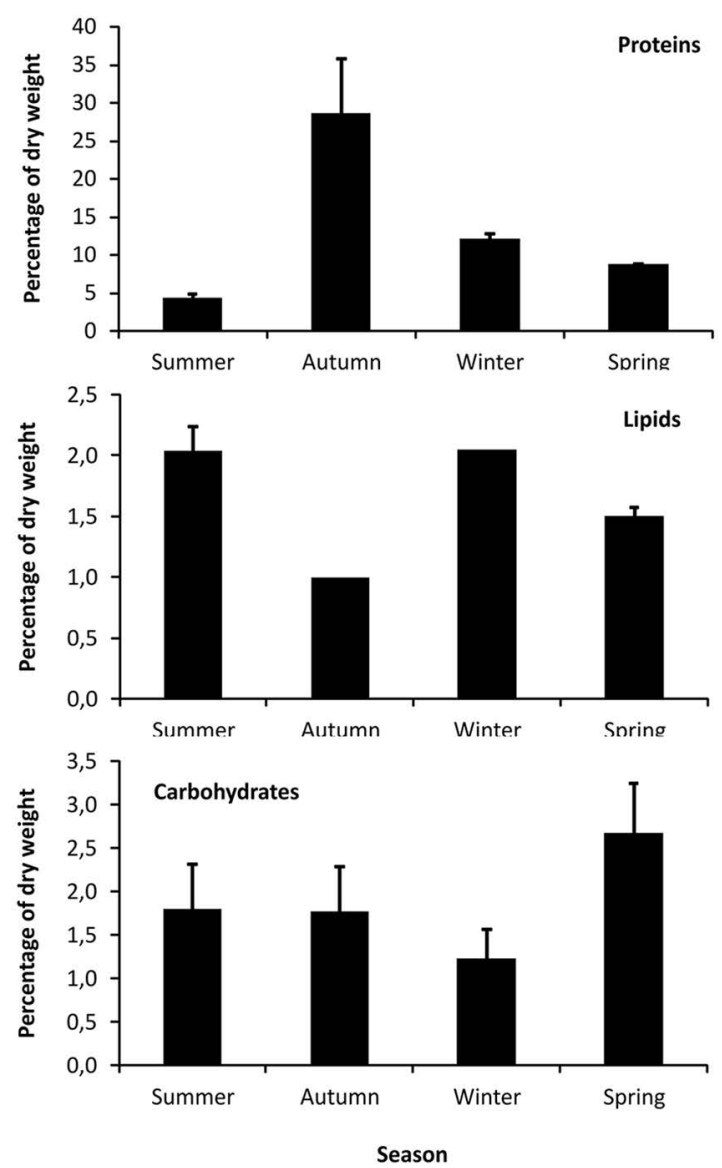

Figure 8. Average values (bars) and standard deviation (lines) of the percentage of the proteins, lipids and carbohydrates on the dry weight for the Hydrozoa Rhacostoma atlanticum.

Tamoya haplonema (NOGUEIRA JÚNIOR; HADDAD, 2006a) probably influenced by the Brazil current in the region. The study conducted by NOGUEIRA JÚNIOR et al. (2010), also on the Santa Catarina coast, reported the same species of macromedusae as those reported in this study. Their investigation also highlights great variability in density values between sampling years, and the possible influence of oceanographic conditions on the population density along the coast - as also on the reproduction of the organisms.

The density variations observed for the organisms, and the distribution of the different life cycle stages of macromedusae, may therefore be related to characteristics of the ecosystem. For both $O$. sambaquiensis and $R$. atlanticum, species common in the south of Brazil, their occurrence has been reported in high densities in waters with temperatures of between 19.5 and $21.0^{\circ} \mathrm{C}$ during the spring (MIANZAN; GUERRERO (2000) and NOGUEIRA
JÚNIOR et al. (2010), despite the different behaviors of the same species as between the southeastern and southern regions of Brazil (NOGUEIRA JÚNIOR et al., 2010). Their cohorts appear to have been more influenced by the climatic conditions in 2014 , characterized by milder winters and low influence of the continental drainage (higher salinities), suggesting favorable conditions for the development of the species. This fact was also suggested by RUIZ et al. (2012) for Cotylorhiza tuberculata (Scyphozoa) in the Mediterranean, where the polyp's survival is strongly influenced by water temperature.

The differences in abundance between $O$. sambaquiensis and $R$. atlanticum can be attributed to their reproductive capacity and survival rates in the critical phases, as in the planule larva and in the process of its settling. It appears that $O$. sambaquiensis presents greater energy investment in the maturation of the gonads than $R$. atlanticum, which would lead to more clearly defined cohorts, and a greater constancy of occurrence between sampling years.

Associated with this, the possible seasonality observed for the constituents of the organic matter of $R$. atlanticum indicated higher protein content in the reproduction period, and higher densities of the species. According to LUCAS (1994), this biomolecule is used as an energy reserve, and is more abundant in the gonads than in the umbrella. Furthermore, the high content of carbohydrates in the spring could be interpreted as the recovery of energy reserves that had been depleted during the reproductive stage (winter), when the species presented the lowest levels of this biomolecule. It appears that this seasonal characteristic in the chemical composition of $R$. atlanticum may be followed by other species, such as $O$. sambaquiensis, but this datum still needs to be proved.

In terms of population characteristics, the biometric data and the relationships between size and weight obtained in this study are within the range presented by NOGUEIRA JÚNIOR and HADDAD (2006b) and NOGUEIRA JUNIOR et al. (2010) in their works on the Paraná and Santa Catarina coasts and contribute to validations of the estimates of biomass, based on the size distribution and on observations in situ (HADDOCK, 2004).

The balance between the three biomolecules that constitute the organic matter (proteins, lipids and carbohydrates) provides important information about the biochemical characteristics of the organism, and the nutritional status, or phase of life cycle that the organism is in. The higher content of organic matter obtained for Cubozoa, in relation to the other species, indicates a possible ecological 
importance of the group in the pelagic system or the presence of differentiated organelles, such as a more developed nervous system (RUPPERT et al., 2004). In general, the order of importance of the protein, lipid and carbohydrate contents obtained in this study are in agreement with those given in LUCAS (1994) and DOYLE et al. (2007); however, a higher proportion of carbohydrates was observed for the species of the south coast of Brazil. This may be associated with local characteristics, or the low accuracy of the analytical method. However, despite the differences observed in the biochemical composition between box jellyfish (Cubozoa) in relation to the other classes, NAGATA et al. (2015) did not observe any marked differences in trophic position between jellyfish, based on radioactive markers, that might explain the different food sources of the species.

The metals composition of macromedusae reflect the composition of the major elements of the seawater, in terms of $\mathrm{Mg}^{2+}, \mathrm{K}^{+}$and $\mathrm{Ca}^{2+}$. However, for the $\mathrm{Cu}^{2+}$ (copper) and $\mathrm{Sr}^{2+}$ (strontium), it appears that the tissues of macromedusae are enriched by these smaller elements. As for the $\mathrm{Sr}^{2+}$, with high concentrations in all species, it is of no physiological importance, and is unrelated to associated toxicity problems (FÖRSTNER; WITTMANN, 1981). However, $\mathrm{Cu}^{2+}$ presented significant concentrations for all species, and is an essential metal that plays a role in the metabolic pathways of plants and animals, but which can be toxic when present in high concentrations (ALEXANDER; CORCORAN, 1967). According to the Ministry of Health of BRAZIL (1998), the limit of $\mathrm{Cu}^{2+}$ in food for human consumption is $10 \mathrm{mg} \mathrm{kg}^{-1}$, a value well above the $1 \mathrm{mg} \mathrm{Kg}^{-1}$ of the fresh medusa obtained in this study.

In conclusion, this study affirms that six species of macromedusae have been found on the north coast of Santa Catarina. The species of the highest occurrence, and typical of the region, were Olindias sambaquiensis and Rhacostoma atlanticum, which showed high variability over the years, the highest densities being obtained between autumn and winter 2014, and are associated with milder winters and saltier waters. Cubozoa presented higher organic matter content, and were also rich in metals in the ash. $R$. atlanticum presented a possible seasonality in its chemical composition, the proteins being related to the reproductive peak of the species.

\section{ACKNOWLEDGEMENTS}

We wish to thank the Coordination for the Improvement of Higher Education Personnel (CAPES) for the research grant, and the National Council for Scientific and Technological Development (CNPq) for the resources granted under research project processes 484467/2012-3 and 406583/2012-9 and by PQ grant process 305795/2014-7.

\section{REFERENCES}

ALEXANDER, J. E.; CORCORAN, E. F. The distribution of copper in tropical seawater. Limnol. Ocean., v. 12, n. 2, p. 236-242, 1967.

AOAC. Official Methods of Analysis. 16th ed. Gaithersburg: Association of Official Analytical International, 1995.

BRANCO, J. O.; VERANI, J. R. Pesca do camarão sete-barbas e sua fauna acompanhante, na Armação do Itapocoroy, Penha, SC. In: BRANCO, J. O.; MARENZI, A. W. C. (Orgs.). Bases ecológicas para um desenvolvimento sustentável: estudos de caso em Penha, SC. Itajaí: UNIVALI, 2006. p. 153-170.

BRASIL. Ministério da Saúde. Portaria ${ }^{\circ}$ 685, de 27 de agosto de 1998. Diário Oficial da União. Poder Executivo. Brasília, 1998.

CARVALHO, J. L. B.; SCHETTINI, C. A. F.; RIBAS, T. M. Estrutura termohalina do litoral Centro-Norte Catarinense. Notas Téc. FACIMAR, v. 2, p. 181-197, 1998.

DOYLE, T. K.; HOUGHTON, J. D. R.; MCDEVITT, R.; DAVENPORT, J.; HAYS, G. C. The energy density of jellyfish: Estimates from bomb-calorimetry and proximate-composition. J. Exp. Mar. Biol. Ecol., v. 343, n. 2, p. 239-252, 2007.

DUBOIS, M.; GILLES, K. A.; HAMILTON, J. K.; REBERS, P. A.; SMITH, F. Colorimetric method for determination of sugars and related substances. Anal. Chem., v. 28, n. 3, p. 350-356, 1956.

EATON, A. D.; CLESCERI, L. S.; GREENBERG, A. E.; FRANSON, M. A. H. Standard methods for the examination of water and wastewater. Washington: American Public Health Association, 1992.

FÖRSTNER, U.; WITTMANN, G.T.W. 1981. Metal Pollution in the Aquatic Environment. Springer-Verlag. Berlin. 2nd Edition. 486p.

HADDAD JÚNIOR, V.; SILVEIRA, F. L.; MIGOTTO, A. E. Skin lesions in envenoming by cnidarians (Portuguese Man-of-war and Jellyfish): Etiology and severity of accidents on the Brazilian Coast. Rev. Inst. Med. Trop. São Paulo, v. 52, n. 1, p. 47-50, 2010.

HADDOCK, S. H. D. A golden age of gelata: past and future research of planktonic cnidarians and ctenophores. Hydrobiologia, v. 530, n. 1, p. 549-556. 2004.

LUCAS, C. H. Biochemical composition of Aurelia aurita in relation to age and sexual maturity. J. Exp. Mar. Biol. Ecol., v. 183, n. 2, p. 179-192, 1994.

MARQUES, A. C.; MORANDINI, A. C.; MIGOTTO, A. E. Synopsis of knowledge on Cnidaria Medusozoa from Brazil. Biota Neotrop., v. 3, n. 2, p. 1-18, 2003.

MIANZAN, H. W.; GUERRERO, R. A. Environmental patterns and biomass distribution of gelatinous macrozooplankton. Three study cases in the South-western Atlantic Ocean. Sci. Mar., v. 64, n. Supl. 1, p. 215-224, 2000.

MILLS, C. E. Jellyfish blooms: are populations increasing globally in response to changing ocean conditions? Hydrobiologia, v. 451, n. 1, p. 55-68, 2001.

MORANDINI, A. C.; ASCHER, D.; STAMPAR, S. N.; FERREIRA, J. F. V. Cubozoa e Scyphozoa (Cnidaria: Medusozoa) de águas costeiras do Brasil. Iheringia Sér. Zool., v. 95, n. 3, p. 281-294, 2005. 
NAGATA, R. M.; HADDAD, M. A.; NOGUEIRA JÚNIOR, M. The nuisance of medusae (Cnidaria, Medusozoa) to shrimp trawls in central part of southern Brazilian Bight, from the perspective of artisanal fishermen. Panam. J. Aquat. Sci., v. 4, n. 3, p. 312-325, 2009.

NAGATA, R. M.; MOREIRA, M. Z.; PIMENTEL, C. R.; MORANDINI, A. C. Food web characterization based on $\delta^{15} \mathrm{~N}$ and $\delta^{13} \mathrm{C}$ reveals isotopic niche partitioning between fish and jellyfish in a relatively pristine ecosystem. Mar. Ecol. Prog. Ser., v. 519, p. 13-27, 2015.

NOGUEIRA JÚNIOR, M.; HADDAD, M. A. Macromedusae (Cnidaria) from the Paraná coast, southern Brazil. J. Coastal Res., v. 39, p. 1161-1164, 2006a.

NOGUEIRA JÚNIOR, M.; HADDAD, M. A. Relações de tamanho e peso das grandes medusas (Cnidaria) do litoral do Paraná, Sul do Brasil. Rev. Bras. Zool., v. 23, n. 4, p. 12311234, 2006b.

NOGUEIRA JÚNIOR, M.; NAGATA, R. M.; HADDAD, M. A. Seasonal variation of macromdusae (Cnidaria) at North Bay, Florianópolis, southern Brazil. Zoologia, v. 27, n. 3, p. 377386, 2010.

PIOLA, A. R.; MATANO, R. P.; PALMA, E. D.; MÖLLER JR., O. O.; CAMPOS, E. J. D. The influence of the Plata River discharge on the western South Atlantic shelf. Geophys. Res. Lett., v. 32, p. L01603, 2005.

PURCELL, J. E.; UYE, S.; LO, W. T. Anthropogenic causes of jellyfish blooms and their direct consequences for humans: a review. Mar. Ecol. Prog. Ser., v. 350, p. 153-174, 2007.
RAMIREZ, F. C.; ZAMPONI, M. O. Hydromedusa. In: BOLTOVSKOY, D. (Ed.) Atlas del zooplancton del Atlantico Sudoccidental y métodos de trabajo con zooplancton marino. Publicación especial del Instituto Nacional de Investigación y Desarrollo Pesquero. Mar Del Plata: INIDEP, 1981. p. 443469.

RESGALLA JR., C. The holoplankton of the Santa Catarina coast, southern Brazil. An. Acad. Bras. Ciênc., v. 83, n. 2, p. 575-588, 2011.

RUIZ, J.; PRIETO, L.; ASTORGA, D. A model for temperature control of jellyfish (Cotylorhiza tuberculata) outbreaks: A causal analysis in a Mediterranean coastal lagoon. Ecol. Modell., v. 233, p. 59-69, 2012.

RUPPERT, E. E.; FOX, R. S.; BARNES, R. D. Invertebrate Zoology: A Functional Evolutionary Approach. 7th ed. Belmont: Brooks/Cole-Thomson Learning, 2004. p. 153154.

SCHROEDER, R.; BRANCO, J. O.; FREITAS JR., F.; RESGALLA JR., C. Preliminary assessment of the jellyfish bycatch captured off southern and southeastern Brazil. Lat. Am. J. Aquat. Res., v. 42, n. 2, p. 289-300, 2014.

VON SOXHLET, F. "Die gewichtsanalytische Bestimmung des Milchfettes". Dingler's Polytechnisches Journal (in German) v. 232, p. 461-465.

WIEBRING, A.; HELMHOLZ, H.; LASSEN, S.; PRANGE, A.; JARMS, G. Separation and analysis of different types of nematocysts from Cyanea capillata (L.) medusa. Hydrobiologia, v. 645, n. 1, p. 203-212, 2010. 